\title{
CROSS-BORDER DISPUTES ON ON-LINE CONSUMER CONTRACTS IN THE EUROPEAN UNION. THE BRUSSELS CONVENTION, THE BRUSSELS REGULATION AND THE ROLE OF ALTERNATIVE DISPUTE RESOLUTION SYSTEMS
}

\section{INTRODUCTION}

This paper is devoted to the study of a topic which has been subject to extraordinary controversy and to a deep review in the European Community during the last two years. That is to say, the jurisdiction over consumer contracts concluded on the Internet. At present, this subject is governed by the Brussels Convention on jurisdiction, recognition and enforcement of judgements in civil and commercial matters. ${ }^{1}$ This Convention includes certain special rules on jurisdiction for these contracts in order to protect consumers. However, these provisions were drafted at a time when the success of electronic commerce was impossible to predict. The special features of Internet and the manner in which on-line transactions take place demanded an adaptation of those rules to the new environment.

In July 1999, the European Commission presented a Proposal for Council Regulation ${ }^{2}$ to convert the Convention into a Community Act and also to incorporate numerous amendments. ${ }^{3}$ The Proposal specified

\footnotetext{
* Assistant of Private International Law, University of Alicante (Spain).

1 Brussels Convention on Jurisdiction and the Enforcement of Judgements in Civil and Commercial Matters of 27 September 1968. [1998] OJ 26 January 1998 L 27/1 (Consolidated Version).

2 OJ [1999] C 376/1, 28 of December 1999. Available at the University of Alicante Internet Portal of Intellectual property and Information Technologies http://www.uaipit. com

3 The legal basis of the Proposal is new Art. 61(c) of the EC Treaty. It is included in new Title IV "Visas, asylum, immigration and other policies related to free movement of persons" created by the Treaty of Amsterdam. Once the UK and Ireland have "opted in" in the manner provided in "Protocol $\mathrm{N}^{\circ} 4$ on the position of United Kingdom and Ireland" annexed to TOA, only Denmark remains excluded from the Brussels Regulation by virtue of "Protocol $N^{\circ} 5$ on the position of Denmark". Domestic courts of Member States bound
} 
that contracts concluded between a consumer and a professional who, by any means, directs his activities to the consumer's residences shall deserve special protection.

Once the European Parliament had adopted its Report ${ }^{4}$ and the Commission had presented an Amended Proposal, ${ }^{5}$ Council Regulation 44/2001 on Jurisdiction and the Enforcement of Judgements in Civil and Commercial Matters - hereafter referred to as the Brussels Regulation was finally adopted by the Council on December 22, 2000. ${ }^{6}$ The instrument will not enter into force until March 1, 2002. ${ }^{7}$ In the meanwhile, the Brussels Convention will still apply. It is worth analysing to what extent the amendments included in the Regulation modify the existing legal treatment of consumer contracts, whether they adapt to electronic commerce, and whether they are justified.

For the above-mentioned purposes, we first look at the kind of contractual relations we are dealing with and the reasons which lead legal systems to protect the consumers in international contracts (Chapter II). We continue with a brief explanation of the three regimes on jurisdiction for consumer contracts, which can be found in the Brussels Convention and the Brussels Regulation (Chapter III). We then concentrate on the study of the provisions which govern disputes over on-line consumer contracts which deserve special protection. An explanation is given on how the Regulation modifies the legal treatment of these contracts (Chapter IV). Despite the fact that they were not taken into account, some mention is made of the amendments proposed in the European Parliament Report. They raise the issue of the use of alternative dispute resolution systems in electronic commerce (Chapter V). We close this contribution with some final remarks (Chapter VI).

\section{On-Line CONSUMER CONTRACTS}

Businesses are beginning to use the World Wide Web (WWW) to trade in products and services. Placing a web site on the WWW is extremely

by the Regulation will have to apply the Brussels Convention in those cases where the defendant is domiciled in that State.

4 Document A5-0253/00, drafted by Ms. Diana Wallis. The competence of the Parliament is stated in Art. 67. The Report is adopted in accordance with Art. 250(2) of the EC Treaty and it is of a non-binding nature.

5 Doc COM (2000) 689 final, of 26 November 2000. Available at $h t t p: / / w w w . u a i p i t . c o m$

6 OJ [2001] L 12/1, of 16 January 2001. All the documents of the procedure of adoption are available at http://www.uaipit.com

7 Art. 76. 
cheap and it enables small and medium enterprises (SME) to access and to compete with stronger companies in the markets of foreign countries. Web sites can be constructed exclusively as advertisements; however, they provide other possibilities to their owners. Web sites may allow consumers to examine or use the products in a restricted form and they can provide after-sales information. Moreover, thanks to its interactive nature, a web site can also assist the supplier to complete the sale: purchases can now be concluded through web sites. This latter characteristic is used to distinguish between interactive and passive web sites.

The first ones are pre-programmed computer programs, which may automatically manifest the assent of the web site's owner to conclude a contract once the consumer has submitted the required information. ${ }^{8}$ These transactions are commonly known as click-wrap agreements. ${ }^{9}$ They are the electronic equivalent of shrink-wrap licenses for computer programs. ${ }^{10}$ Before purchasing the product, the user is required to review an agreement, which is displayed on the screen, and then to click on a box stating that the user accepts the terms of the agreement ${ }^{11}$ - an "I agree" icon. Once this has been done, it is considered that the consumer accepts the contractual terms. Passive web sites are only used for advertising purposes or in order to give consumers the opportunity to examine the quality of the product or service. However, on-line commerce can also exist if these passive web sites allow Internet consumers to make an order by e-mail. In both cases, the law applicable to the contract may require for its conclusion a supplier's acknowledgement of the consumer's order. ${ }^{12}$

\footnotetext{
8 Such web sites form part of so-called electronic agents.

9 They may receive different names: webwrap licenses, mass-market licenses, 1-click license, bootscreen licenses ...

10 "In place of the conventional license agreement signed by both parties, the software is supplied in a sealed clear plastic package through which can be seen the terms of the license agreement. This document is usually headed by a warning in prominent letters to the effect that a person breaking the wrapping will be deemed to have agreed to all the terms and conditions of the license". See Ranald Robertson, Legal Protection of Computer Software, 1st Ed., Longman, 1990, p. 11.

11 For example, a web site offering software for sale. The user selects the icon of the software that he wishes which is $\$ 120$. A screen will display and the terms of the license are explained and a button saying "I agree". Once the consumer has entered the required information - such as name, domicile, country, telephone and credit card number - and he has clicked the button, the contract is concluded.

12 This is one of the essential questions of electronic contracts. Art. 11 of the Directive 2000/31 on Certain Aspects of Information Society Service, in Particular Electronic Commerce, in the Internal Market (Directive on Electronic Commerce) (OJ [2000] 17 July 2000, L 178/1) leaves the answer to the Member States legislations. Available at http://www.uaipit.com
} 
Although it is not overly common, retailers may also try to reach clients by e-mail. The use of "spam" has become very popular. It is the electronic equivalent to junk mail: unsolicited e-mails sent to millions of recipients. ${ }^{13}$ This marketing practice has great advantages because by sending an email there are more chances that the offer will be seen. A web site may be visited by a limited number of Internet users a day or may not be visited at all. Moreover, the ease of computer data processing, sometimes illegal, allows merchants to select the recipients considered to be most interested in their products or services. ${ }^{14}$

Obligations can also be electronically performed. The subject matter of many on-line consumer contracts is intangible goods: images, videos, music, and software. These goods can be electronically "downloaded" from a web site or they can be transmitted by e-mail. On the consumers' side, they can comply with their payment obligation electronically. Very often they will be required to pay in advanc,e thus their position in the contractual relationship becomes even weaker.

Since consumers are still not sufficiently familiar with electronic commerce and are afraid of lack of security on the Internet, it is estimated that a great number of consumers prefer to examine the product on the web site and then to use traditional ways, such as telephone or mail, to conclude the contract. This category does not fall under the scope of this paper insofar as the conclusion of the contract does not take place on the Internet.

As far as on-line contracts are characterized by the presence of a person acting outside his profession - the consumer - and a counterpart who acts within his professional activity - the supplier -, they can be qualified as consumer contracts for legal purposes. ${ }^{15}$ Traditionally, legal systems are concerned with consumer contracts, among other aspects, because one of the parties, the consumer, is thought to be in a weaker bargaining position.

13 The definition is taken from "The Internet - Legal Issues, Legal Resources" in http://blueriver.net/ (not available anymore). In order to get e-mail addresses, spammers enter Usenet groups, which are available to anybody connected to the Internet so long as they have the appropriate software. Since people join the Usenet group depending on the topic, they know what kind of products or services interest those persons. The possibilities of a successful advertising campaign thus grow.

14 The use of spam is subject to strict rules in the EC. See Art. 10 of the Directive 97/7 on Distance Consumer Contracts ([1997] OJ, 4 June 1997, L 144/19), Art. 7 of the Directive on Electronic Commerce, Directive 95/46 on the protection of individuals with regard to the processing of personal data and on the free movement of such data ([1995] OJ 23 November 1995 L 281/31) and Art. 12 of Directive 97/66 concerning the processing of personal data and the protection of privacy in the telecommunications sector ([1998] OJ of 30 January 1998, L 24/1). Documents available at http://www.uaipit.com

15 See Art. 2 of Directive 97/7. 
This situation appears in standard-form contracts where merchants unilaterally impose terms - unfair terms - which benefit his position and directly impair that of the consumer who cannot negotiate the terms, and who limits his role to the signing of the contract. Electronic commerce requires the use of standard terms. Click-wrap agreements consist of standard-term contracts, which are displayed on the screen, and the Internet user decides whether to click on the "I agree" icon or not. To the extent that there is no person on the other side of the screen, it is impossible for negotiation to take place. The acceptance of the Internet user is filed by the electronic agent - the web site's computer system - and the conclusion of the contract may or may not depend on the confirmation of the web site's owner.

In international consumer contracts, suppliers may include forumchoice clauses in the standard terms, which oblige the consumer to litigate in a third state - frequently the supplier's domicile state. This may have two consequences for the consumer. First, he will find many difficulties to obtain quick access to justice and adequate redress in such a manner that his legal rights would be emptied out of any content. He would be forced to litigate in a legal system which is strange to him and whose procedural and substantive laws are also unfamiliar. It would also be the case that the counterpart is better prepared for litigation and has stronger economic resources than those of the consumer. Second, these clauses frequently dissuade consumers from suing because of the high costs of litigation in a distant state and the often irrelevant economic interests that the complaint implies. ${ }^{16}$ At last, the consumer would renounce his claim to rights.

These reasons led the drafters of the Brussels Convention and the Lugano Convention ${ }^{17}$ to include special provisions, which aim to protect the consumer from those abuses. However it was considered that not every consumer contract qualifies for special protection. Three different regimes can be distinguished.

16 L. Carrillo Pozo: "Comentario al Art. 13" en Calvo Caravaca (edi), Comentario al Convenio de Bruselas relativo a la competencia judicial y a la ejecución de resoluciones judiciales en materia civil y mercantil, Madrid, Universidad Carlos III - BOE, 1994, pp. 270-271.

17 Lugano Convention on Jurisdiction and the Enforcement of Judgements in Civil and Commercial Matters of 16 September 1988 [1988] OJ 25 November 1988 L 319/9. The Lugano Convention, also called the Parallel Convention, has almost the same content as the Brussels Convention, but while the latter is only applicable by EC Members, Lugano Convention is applied in the EFTA countries - that is to say all EC Member States plus Switzerland, Liechtenstein, Norway and Iceland. Since the content is similar, we can analyse both conventions at the same time.

Since EC countries are parties to both conventions, their courts may decide whether to apply one or the other. That question is solved by Art. 54 of the Lugano Convention. 


\section{JURISDICTION OVER CONSUMER CONTRACTS IN THE EUROPEAN UNION}

The scope of application of the Convention - and the Regulation - is all "civil and commercial matters"18 except for those listed in Art. 1(2). ${ }^{19}$ The initial purpose of the conventional instrument was to establish a simplified system of recognition and enforcement of judgements. ${ }^{20}$ However, the negotiators believed that it would be impossible to reach an agreement if the rules on jurisdiction of the different Member States were not unified. For that purpose, Title II of the Convention was included.

The rules on jurisdiction are organized hierarchically. For all consumer contracts, Art. 18 (new Art. 24 in the Brussels Regulation) ${ }^{21}$ has primacy over the rest of the rules. That provision applies when the plaintiff brings the dispute before a court, which, according to the rules of the Convention, has no jurisdiction, but, as far as the defendant does not contest it, it has to be considered that he has tacitly accepted that domestic court to hear the case. It is a provision which applies to contracts in general and which does not take into account if one of the parties is a consumer. The reason not to provide a different solution for consumer contracts in this specific case

18 "Civil and commercial matters" is an autonomous notion whose content has been interpreted several times by the ECJ. See C-29/76 LTUv. Eurocontrol [1976] ECR 1541, C9 and 10/77 Bavaria v. Eurocontrol [1977] ECR 1517, C-133/78 Gourdain/Nadler [1979] 733, C-143/78 De Cavel/De Cavel (I) [1979] ECR 1050, C 25/79, Sanicentral/Collin [1979] ECR 3423, C 120/79 De Cavel/De Cavel (II) [1980] ECR 731, C 784/79 Porta Leasing/Prestige Int. [1980] ECR 1517, C 814/79, [1980] ECR 3807, C-25/81 Marc Rich/Impianti [1982] ECR 1189, C-190/89, Volker Sonntag/Hans Waidman e.a. [1991] ECR I-3855, C-172/91 [1993] ECR I-1963, C 220/95 A. van den Boogard/P. Laumen [1997] ECR I-1147.

19 Par. 2 reads: "The Convention shall not apply to:

1. the status or legal capacity of natural persons, rights in property arising out of a matrimonial relationship, wills and succession;

2. bankruptcy, proceedings relating to the winding-up of insolvent companies or other legal persons, judicial arrangements, compositions and analogous proceedings;

3. social security;

4. arbitration."

20 Indeed, it has been said that the Brussels Convention has established the fifth freedom of movement in the EC: the free movement of judgements. See J.L. Iglesias Buhigues, M. Desantes Real: "Competencia judicial y ejecución de sentencias en Europa", en AAVV, $E l$ Derecho Comunitario Europeo y su aplicación judicial, Madrid, Civitas, 1993, pp. 10471066. See also the Memorandum on the Commission Proposal for a Regulation.

21 New Art. 24 reads: "Apart from jurisdiction derived from other provisions of this Convention, a court of a Contracting State before whom a defendant enters an appearance shall have jurisdiction. This rule shall not apply where appearance was entered solely to contest the jurisdiction, or where another court has exclusive jurisdiction by virtue of Article 16 (new Art. 22)". 
is because, in such a situation, the consumer is free to decide whether he would be impaired if he submits himself to a jurisdiction which is different to those established by the Convention for his protection. ${ }^{22}$

In case the conditions of Art. 18 are not met; jurisdiction of the court should be determined in accordance with other provisions of the Convention. At this point, it is necessary to distinguish among three different regimes depending on whether the contract fulfils the requirements of Art. 13 or not, and whether the defendant is domiciled in a Contracting State or not.

First regime. For disputes where the defendant is domiciled in conventional territory and where the contract falls under Art. 13 (new Art. 15), the special rules on jurisdiction provided in Arts. 14 and 15 (new Arts. 16 and 17) apply. The drafters of the Convention understood that only those contracts where some objective requirements manifesting the weak bargaining position of the consumer are met, deserve to be protected. These requirements are stated in Art. $13 .{ }^{23}$ Their study becomes very important, since their presence determines the legal regime applicable to on-line consumer contracts. Only if on-line consumer contracts fall under this regime will consumers benefit from special protection.

Arts. $14^{24}$ aims to safeguard consumer's interests and thus they give him the possibility to sue his counterpart either in the latter's state of domicile or in his own domicile. On the other hand, if the supplier wants to sue the consumer he must bring the case before the courts of the consumer's domicile state. ${ }^{25}$

22 In Elefanten Schuh, the ECJ sustain the primacy of Art. 18 over Art. 17. Even if the parties have chosen the forum in the contract, if the plaintiff submits the case to another court and the defendant does not contest the jurisdiction, that court will gain competence to know the dispute. C-150/80 Elefanten Shuch v. Jacqmain [1981] ERC 1671.

23 Art. 13 can be found in page 11.

As it can be seen Par. 3 of this provision receives a complete new wording under the Brussels Regulation.

24 New Art. 16: "A consumer may bring proceedings against the other party to a contract either in the courts of the Contracting State in which that party is domiciled or in the courts of the Contracting State in which he is himself domiciled.

Proceedings may be brought against a consumer by the other party to the contract only in the courts of the Contracting State in which the consumer is domiciled.

These provisions shall not affect the right to bring a counter-claim in the court in which, in accordance with this Section, the original claim is pending."

25 Reasons such as lower costs and quicker access to justice may lead the consumer to sue his counterpart in his own domicile; reasons of an adequate and quick enforcement of the eventual judgement may push the consumer to bring the dispute before the courts of the supplier's domicile. See E. Zabalo Escudero: "Aspectos juridicos de la proteccion al consumidor contratante en el Derecho internacional privado" in Revista Española de Derecho Internacional, vol. XXXVII, 1-1985, p. 129. 
Pursuant to Art. 15, choice of forum by express agreement in these contracts may be exercised, but one of these conditions must be present: (1) the agreement must have been entered into after the dispute has arisen; or (2) the forum-choice clause has to allow the consumer to bring proceedings in courts other than those indicated in Art. 14; or (3) in the case where both the consumer and the supplier are, at the conclusion of the contract, domiciled in the same state they may agree to submit any dispute before its courts. ${ }^{26}$ In these situations the consumer's interests cannot be considered to be in danger. In the first case, it is a free choice of the consumer to the extent that they are forum-choice agreements which are not included in standard-form contracts; in the second place, they provide further alternative fora for the consumer to sue the supplier; finally, they are justified in the close connection with the particular state. ${ }^{27}$ Choice of any other forum will be invalid for the purpose of the Convention.

The Brussels Regulation does not include important changes in the wording of Arts 14 and 15 (new 16 and 17). Otherwise Art. 13, as we will see, has been amended by new Art. 15 to extend the scope of consumer contracts, which benefit from the special protection.

Second regime. For disputes where the defendant is domiciled in the Community but the consumer contract does not meet the conditions of Art. 13, the Convention understands that special protection should not be afforded, and therefore general provisions on contracts apply. When a choice of forum has been previously agreed by the parties, Art. 17 (new Art. 23) lays down two conditions to give validity to the agreement: (1) at least one of the parties must be domiciled in a contracting state; and (2) one of the conditions listed in letter (a), (b) and (c) is fulfilled. Most of the times, the consumer contract will fulfil the condition in (a) insofar as forum-choice clauses are included in standard-form contracts which are always in writing or whose conclusion is followed by some written evidence that is sent to the consumer. ${ }^{28}$

\footnotetext{
26 New Art. 17: "The provisions of this Section may be departed from only by an agreement:

1. which is entered into after the dispute has arisen; or

2. which allows the consumer to bring proceedings in courts other than those indicated in this Section; or

3. which is entered into by the consumer and the other party to the contract, both of whom are at the time of conclusion of the contract domiciled or habitually resident in the same Contracting State, and which confers jurisdiction on the courts of that State, provided that such an agreement is not contrary to the law of that State."

27 E. Zabalo Escudero: "Aspectos juridicos de la proteccion al consumidor ...", p. 130.

28 New Art. 23(1) reads: "If the parties, one or more of whom is domiciled in a Contracting State, have agreed that a court or the courts of a Contracting State are to have jurisdiction to settle any disputes which have arisen or which may arise in connection with a particular legal relationship, that court or those courts shall have exclusive jurisdiction.
} 
In cases where the parties have not exercised this choice of forum, the defendant may still be sued in the general forum of Art. 2 - defendant's domicile $-{ }^{29}$ or in the alternative forum of the place of performance of the obligation in question as established in Art. 5(1). ${ }^{30}$

Third regime. Finally, for those disputes where the defendant is domiciled outside conventional territory, if the parties have not chosen the forum, pursuant to Art. 4, national courts must apply their national laws

Such an agreement conferring jurisdiction shall be either:

(a) in writing or evidenced in writing; or

(b) in a form which accords with practices which the parties have established between themselves; or

(c) in international trade or commerce, in a form which accords with a usage of which the parties are or ought to have been aware and which in such trade or commerce is widely known to, and regularly observed by, parties to contracts of the type involved in the particular trade or commerce concerned".

A new paragraph has been included which may have some relevance for on-line transactions: Par. 3 says: "Any communication by electronic means which provides a durable record of the agreement shall be equivalent to writing".

29 Art 2: "Subject to the provisions of this Convention, persons domiciled in a Contracting State shall, whatever their nationality, be sued in the courts of that State.

Persons who are not nationals of the State in which they are domiciled shall be governed by the rules of jurisdiction applicable to nationals of that State".

A number of reasons justify the general character of this forum. In principle, if a person is domiciled in a contracting state, he should be aware that he might be sued in that state. It is the forum which best safeguards the due process and the legitimate expectations of the individuals. It is the environment where he develops his economic and social life and since it is the legal system where his legal relations take place it is reasonable to expect that he knows it well.

According to G.A.L. Droz, "Cette règle et l'expression de l'adage actor sequitur forum rei ... Elle exprime la faveur de droit envers celui qui se defend. Generalisée en droit interne, elle se justifie encore plus dans les rapports internationaux puisqu'il est plus difficile de se defendre á l'ètranger que chez soi'. In Competence judiciaire et effets des jugements dans le marché commun - Etude de la Convention de Bruxelles du 27 septembre 1968, Dalloz, Paris, 1972, p. 53.

30 Art. 5 says: "A person domiciled in a Contracting State may, in another Contracting State, be sued: (1) in matters relating to a contract, in the courts for the place of performance of the obligation in question".

The Regulation gives a new wording to Par. 1: “(a) in matters relating to a contract, in the courts for the place of performance of the obligation in question;

(b) for the purpose of this provision and unless otherwise agreed, the place of performance of the obligation in question shall be:

- in case of the sale of goods, the place in a Member State where under the contract the goods were delivered or should have been delivered;

- in case of the provision of services, the place in a Member State where under the contract the services were provided or should have been provided;

(c) if paragraph (b) does not apply, then paragraph (a) applies." 
to gain jurisdiction over the dispute. ${ }^{31}$ It makes no difference whether the consumer contract meets the requirements of Art. 13 (new Art. 15) or not.

It is the purpose of the following chapter to explain the applicable regime to on-line consumer contracts in cases where the defendant is a European on-line business domiciled in conventional territory - First regime. It is the regime which would eventually apply to a higher number of cases and which has created more controversy. At the same time, an assessment will be made on the amendments the Regulation brings into this regime.

\section{The Application of the Special Rules on JuRisdiction to ON-LINE CONSUMER CONTRACTS UNDER THE BRUSSELS CONVENTION AND THE BRUSSELS REgULATION}

\subsection{Introduction}

The first thing domestic courts must look at when applying the Convention is the place where the defendant is domiciled. This determines not only which courts have general jurisdiction over the dispute, but also whether the rules on jurisdiction of the Convention apply. ${ }^{32}$

Given the existence of the Lugano Convention, and the fact that in Denmark the Brussels Regulation will not be applicable, we are obliged

\footnotetext{
The new wording of the Article finishes with the ECJ case law according to which the place of performance of the obligation had to be determined pursuant to the law established by the conflict of law rule of the forum (Case 12/76 Tessili [1976] ECR 1473). Letter (b) establishes an autonomous definition of place of performance of the obligation in question in two specific situations: sales of goods and provisions of services. It applies regardless of the obligation, which gave rise to the dispute. This means that, even in cases where it was the non-performance of the pecuniary obligation which gave rise to the dispute, jurisdiction will go to the courts of the place where the goods were or should have been delivered, or the courts of the place where the services were or should have been provided. The rule may, however, be substituted by an explicit agreement by the parties on the place of performance.

Letter (c) applies when the place of performance is not located in a Member State. In that case, the former Tessili case law is called upon to decide on the location of the place of performance of the obligation in question. This case law has been recently confirmed in the Judgement of 28 October 1999 on the Case 440/97, Groupe Concorde and others vs. Captain of the "Suhadiwarno Panjan" and others [1999] ECR I-6324.

31 Art 4(1): "If the defendant is not domiciled in a Contracting State, the jurisdiction of the courts of each Contracting State shall, subject to the provisions of Article 16, be determined by the law of that State".

The Proposal for a Council Regulation substitutes the words Contracting State for "Member State".

32 Art. 3 reads: "Persons domiciled in a Contracting State may be sued in the courts of another Contracting State only by virtue of the rules set out in Sections 2 to 6 of this Title".
} 
to differentiate among four situations in the application of the provisions on consumer contracts: ${ }^{33}$

1. if the defendant is domiciled in a Member State bound by the Regulation, the Regulation shall apply;

2. if the defendant is domiciled in a Member State not bound by the Regulation, the Brussels Convention shall apply;

3. if the defendant is domiciled in a non-EU State which is party to the Lugano Convention, the Lugano Convention is applicable;

4. if the defendant is domiciled in a State that is neither EU member nor party to the Lugano Convention, then the national law of the court determines the jurisdiction. ${ }^{34}$

For the purpose of Art. 13 of the Brussels/Lugano Convention or Art. 15 of the Brussels Regulation, suppliers which are not domiciled in the Community but have a branch, agency or other establishment in one of the Contracting States are considered to be domiciled in conventional territory in disputes arising out of the operations of that branch, agency or establishment.

Unfortunately, Internet has turned the location of territory-based connecting factors into a frustrating dilemma: virtual locations do not correspond to physical locations. ${ }^{35}$ Furthermore, identification of the parties is very difficult to determine for Internet transactions. The determination of the defendant's domicile has the same problem. However, addressing that problem would need a completely new paper because of the

33 See footnote $\mathrm{N}^{\circ}$ 4. It should be taken into account that certain unofficial proposals exist in the Council to deal with the special position of Denmark: either an amendment of the text of the Brussels Convention in the sense of the Regulation, or the derogation of the Brussels Convention and the application of an amended Lugano Convention to Denmark. As the EP Report states, the approval of the first proposal should require an alignment of the Convention with the text of the Regulation before the latter comes into force. If the second proposal is finally accepted, this classification will make no sense.

34 Unless Arts 17 or 18 of the Brussels Convention, or Art. 17 or 18 of the Lugano Convention, or Art. 23 or 24 of the Regulation are applicable.

35 To get in contact with a natural or legal person, there is no need to know the physical location of that person, but only the virtual location of his computer. That will suffice for a computer to find its path through Internet and connect with the other computer so that an exchange of information can take place. Virtual locations do not have any correspondence with physical locations. In that sense, see Post, D., Johnson, D.: "Law and Borders. The Rise of Law in Cyberspace". Stanford Law Review 48, 1996, p. 1367 and Matthew Burnstein "A Global Network in a Compartmentalised Legal Environment" in K. Boele-Woelki and C. Kessedjian (eds), Internet. Which court decides? Which law applies? Quel tribunal décide? Quel droit s'applique?, Kluwer Law International, 1998. 
complexity of an explanation of the technicalities that its solution involves and the several legal texts, which converge in its regulation. ${ }^{36}$

The fact that European businesses offer their services on Internet from a web site hosted by an Information Society service provider located in a different Member State does not imply a change in the domicile of the European business. The place where these merchants locate their computer systems to access the Internet is irrelevant to the determination of their domicile. ${ }^{37}$ Otherwise, on-line businesses would be able to circumvent certain restrictive legislation by placing their web sites on service providers located in countries different from their State of residence.

Once the domicile of the supplier, or his branch, has been located, it can be established whether the provisions in the Convention - or in the Brussels Regulation - are applicable or the Courts have to determine their jurisdiction pursuant to their national laws. In the first case, the next step would be to determine if the on-line consumer contract concluded on Internet fulfils the requirements of Art. 13 (new Art. 15). Only in that case, will the contract benefit from the special protection of Section 4 of Title II (Chapter II in the Regulation). Otherwise, the general provisions over contracts - Arts. 17, 5(1) and 2 (new 23, 5(1) and 2) - would apply and the business would avoid the jurisdiction of the courts of the consumer's residence.

36 Directive 97/7/EC on Distance Consumer Contracts (see infra): According to Art. 4(1)(a), the supplier must provide, prior to the conclusion of the contract, information about its identity and, in case of contracts requiring payment in advance, his address. Art 5 (1) also obliges the supplier to give the consumer "written confirmation or confirmation in another durable medium available and accessible to him of the information referred to in Art. 4(1)(a)".

The Directive 2000/31 on Electronic Commerce (see infra) also includes some provisions in this respect. Art 6 provides that "commercial communications shall comply with the following conditions: (b) the natural or legal person on whose behalf the commercial communication is made shall be clearly identifiable".

The Recommendations of the OECD Council Concerning Guidelines for Consumer Protection in the Context of Electronic Commerce, of December 1999, strengthens the need of businesses engaged in electronic commerce with consumers to provide accurate, clear and easily accessible information about their identity and physical location (Principle III. A). Available at http://www.oecd.org/dsti/sti/it/consumer/

37 This is also the idea embraced in Art. 2(c): "established service provider": a service provider who effectively pursues an economic activity using a fixed establishment for an indefinite period. The presence and use of the technical means and technologies required to provide the service do not, in themselves, constitute an "establishment of the provider". 


\subsection{Requirements of On-line Consumer Contracts to Qualify for Special Protection}

The general principle of Section 4 is the protection of the consumer as the weaker party to the contract. Notwithstanding the exceptions in Art. 15 (new Art. 17), he can sue and can only be sued in the place where he resides.

Section 4 received the title of "Jurisdiction over Consumer Contracts" when UK, Ireland and Denmark accessed to the Convention. ${ }^{38}$ In such a manner, the original scope of contracts included in Art. 13 was extended. ${ }^{39}$ To draft these provisions, the negotiators were inspired by Art. 5 of the Rome Convention of 1980 on the Law Applicable to Contractual Obligations. ${ }^{40}$ Both provisions complement each other. ${ }^{41}$

Present Art. 13 reads:

"In proceedings concerning a contract concluded by a person for a purpose which can be regarded as being outside his trade or profession, hereinafter called 'the consumer', jurisdiction shall be determined by this Section, without prejudice to the provisions of Article 4 and point 5 of Article 5, if it is:

1. a contract for the sale of goods on instalment credit terms; or

2. a contract for a loan repayable by instalments, or for any other form of credit, made to finance the sale of goods; or

3. any other contract for the supply of goods or a contract for the supply of services, and

(a) in the State of the consumer's domicile the conclusion of the contract was preceded by a specific invitation addressed to him or by advertising; and

(b) the consumer took in that State the steps necessary for the conclusion of the contract.

Where a consumer enters into a contract with a party who is not domiciled in a Contracting State but has a branch, agency or other establishment in one of the Contracting

38 Convention of 9 October 1978 on the accession of the Kingdom of Denmark, Ireland and the United Kingdom of Great Britain and Northern Ireland ([1978] OJ 30 October 1978, L 304/1). In fact, Art. 13 of the Brussels Convention is the first provision in EC Law where a definition of consumer is given. Subsequently, it has been included in several Community Acts where a consumer policy has been developed. See Patrick Latham, "La protection des consommateurs" in Commentaire Megret - Le droit de la CE, vol 8 (2eme edition), Editions de lŠUniversité de Bruxelles, 1996, pp. 78-80.

39 E. Zabalo Escudero: "Aspectos juridicos de la proteccion al consumidor contratante en el Derecho internacional privado" in Revista Española de Derecho Internacional, vol XXXVII, 1-1985, pp. 110-111.

40 See Schlosser Report [1979] OJ, 5 March 1979, C 59/117 at 155.

41 Their efficiency would not be the same if a similar disposition did not exist in jurisdiction and applicable law. See L. Carrillo Pozo: "Comentario al Art. 13" en CalvoCaravaca, A. (edi) Comentarios al Convenio de Bruselas relativo a la competencia judicial y al reconomiento y la ejecución de resoluciones judiciales en materia civil y mercantil, Universidad Carlos III- BOE, Madrid, 1994, p. 269. 
States, that party shall, in disputes arising out of the operations of the branch, agency or establishment, be deemed to be domiciled in that State.

This Section shall not apply to contracts of transport."

Art 15 of the Brussels Regulation reads:

"In matters relating to a contract concluded by a person, the consumer, for a purpose which can be regarded as being outside his trade or profession, jurisdiction shall be determined by this Section, without prejudice to Articles 4 and 5(5), if:

1) it is a contract for the sale of goods on instalment credit terms; or

2) it is a contract for a loan repayable by instalments, or for any other form of credit, made to finance the sale of goods; or

3) in all other cases, the contract has been concluded with a person who pursues commercial or professional activities in the State of the consumer's domicile or, by any means, directs such activities to that State or to several States including that State, and the contract falls within the scope of such activities.

Where a consumer enters into a contract with a party who is not domiciled in the Member State but has a branch, agency or other establishment in one of the Member States, that party shall, in disputes arising out of the operations of the branch, agency or establishment, be deemed to be domiciled in that State.

This Section shall not apply to a contract of transport other than a contract which, for an inclusive price, provides for a combination of travel and accommodation."

(Emphasis added where the wording has been amended)

Two conditions are to be fulfilled in accordance to these dispositions to benefit from the special protection of Arts. 14 and 15: (1) the presence of a consumer, and (2) the inclusion of the contract in one of the categories of Par. 1, 2 or 3.

\subsubsection{Definition of Consumer}

First condition is the presence of a "consumer", the weaker party in the contractual relationship. However, the definitions of consumer in the legal systems of the Contracting States vary. The broader the concept, the greater the number of situations that will fall under its scope. In order to avoid differing applications of the provisions of the Section by national courts due to the different legal definitions, the Convention adopted an autonomous notion of consumer: a person who concludes a contract "for a purpose which can be regarded as being outside his trade or profession". Nothing is said about the counterpart of the consumer for a qualification of the contract.

The case law of the European Court of Justice has delimited this autonomous notion of consumer in a number of judgements. In Bertrand, ${ }^{42}$ the Court underlined the need to restrict the use of the Section to protect

42 C-150/77, Bertrand v. Ott, [1978] ECR 1431. Par. 21. 
certain categories of buyers that, due to their weaker economic position vis-à-vis the retailer, need protection. In Hutton, ${ }^{43}$ those persons were defined as the private final consumers. In Benincasa ${ }^{44}$ it was clearly stated that only contracts concluded for the purpose of satisfying an individual's own needs in terms of private consumption come under the provisions of Section 4. Traditionally, a person has been considered a private final consumer when he does not have the purpose of reintroducing the product in the market to make profits. ${ }^{45}$ However, it has recently been properly argued by the doctrine that the concept of consumer has to be adapted to the different fields of economy. Persons, who contract some financial services, may have a lucrative objective but they deserve protection as well as other consumers. ${ }^{46}$ It is important to take this into account to the extent financial services are one of the areas, which may benefit the most from the Internet. ${ }^{47}$

Furthermore, in Hutton the ECJ more severely restricted the situations, which may fall under Art. 13. It considered that the Convention protects the consumer only insofar as he personally is the plaintiff or defendant in proceedings. ${ }^{48}$ Once a consumers' association assumes the legal defence of a person or a group of persons, the cause, which justifies the application of special rules on jurisdiction, is lost. They cannot be considered as a weaker party anymore ${ }^{49}$ With Internet, as disputes over consumer contracts grow, the role of these associations will become very important. ${ }^{50}$ Recent legislation issued by the EC, such as the Council Resolution of January 19,

\footnotetext{
43 C-88/91, Hutton v. TVB, [1993] OJ 9 February 1993, C 35.

44 C-269/95, Benincasa v. Dentalkit s.r.l, [1997] ECR I-3767.

45 C. Esplugues Mota and G. Palao Moreno: "Las Comunidades Europeas y la protección de los consumidores" en Revista General del Derecho, 1993, p. 6772.
}

46 For example an individual who concludes a contract with a financial agency to invest his savings in the stock exchange market. See R. Arenas Garcia: "Tratamiento jurisprudencial del ámbito de aplicación de los foros de protección en materia de contratos de consumidores del Convenio de Bruselas de 1968". Revista Española de Derecho Internacional, 1996-I, p. 46 and following.

47 See the Amended proposal for a European Parliament and Council Directive concerning the distance marketing of consumer financial services and amending Directives 97/7/EC and 98/27/EC. Doc COM(1999) 385 final. Available at http://www.uaipit.com

48 The dispute concerned a company that claimed some rights, which had been assigned to it by a consumer. The company was exclusively acting on behalf of the consumer. The Court understood that the company was acting within its professional activity and thus it could not be qualified as a consumer.

49 In the same sense C. Kessedjian: "L'action en justice des associations de consommateurs et d'autres organisations représentatives d'intérêts collectifs en Europe" Rivista di Diritto Internazionale Privato e Processuale, 1997, p. 281.

50 Council Directive 93/13 on Unfair Terms in Consumer Contracts ([1993] OJ of 25 April 1993, L 95/29). Art 7 obliges Member States to enable consumer association's action 
1999 asks the Commission to promote the involvement of the consumer organizations in dispute resolution schemes on the Internet arena. ${ }^{51}$ They do not benefit from the special provisions to the extent they do not occupy a weaker position vis-à-vis the supplier. European businesses would have to be sued in accordance with general rules on jurisdiction for contracts: Arts. 2 or 5(1).

Some problems may arise when applying Article 13 in those situations where a business concludes a contract pretending that he is a consumer in order to fraudulently benefit from the special protection of Section 4. Those cases may often take place in electronic transactions because of the difficulties to identify the parties on Internet and the easiness to hide the circumstances surrounding the parties in a contractual relationship. If an individual has relied on the special jurisdiction to sue in his state of residence and during the proceedings it is shown that the goods or services are being used in his professional activity, the Court should decline its competence. In the case the Court decides to carry on with the case, it would be very difficult for the plaintiff to enforce an eventual judgement in the state of the defendant's domicile. ${ }^{52}$ Even more the ECJ has considered that a person who concludes a contract with a view to pursuing a trade or profession, not at the present time but in the future, shall not be regarded as a consumer. ${ }^{53}$

As we have said, the Convention does not define the counterpart of the consumer. The Brussels Regulation does not do so either. However, for those contracts included in Par. 3, Art. 15, it is exceptionally stated that the counterpart who enters into a contract with the consumer has to fulfil some conditions: he has to be "a person who pursues commercial or professional activities ...". If that sentence had not have been written it would have been possible to include in Art. 15(3) those contracts, which are usually concluded between two individuals by, e-mail or on certain web sites which have been specially created for that purpose. ${ }^{54}$ This is the so-called "consumer-to-consumer" sector of electronic commerce. It is

in court on behalf of consumers' general interest when a business's standard-form contracts contain unfair terms.

51 See Recital 12 of The Council Resolution on the Consumer Dimension of the Information Society. [1999] OJ 28 January 1999, C 23/3. Available at http://www.uaipit.com

52 Art 28 (new Art. 42) of the Convention enables the requested Court to control the jurisdiction of the requesting Court only when that Court based its competence on Section 2,3 or 4 of Title II.

53 C-269/95, Benincasa v. Dentalkit s.r.l. [1997] ECR I-3767.

54 See as examples, http://www.eBay.com and, in the European context http://www. ibazares 
clear that in those cases there is no justification to protect one of the parties insofar as their position in the contractual relation is balanced.

\subsubsection{Delimitation of the On-line Consumer Contracts Which Deserve Special Protection}

Once we have identified the presence of a consumer in the contractual relationship, it has to be established whether or not the contract fits into one of the categories laid down in Art 13 (Art. 15 in the Regulation). Depending on the subject matter of the contract, the Convention may require certain conditions in order for someone to benefit from the special protection (2.2.2) or not (2.2.1).

\subsubsection{Contracts, which do not Require Further Conditions to Benefit from the Special Protection}

The Art. 13(1) includes "contracts for the sale of goods on instalment credit terms". It has existed since the first text of the Convention. Any online contract with such subject matter would automatically benefit from the special protection. Art. 15(1) has not changed the wording of this category. ${ }^{55}$ The large amount of money, which the transaction may involve, suffices to justify the special protection, which the consumer is granted.

The second category - Art. 13(2) - refers to contracts for loans "repayable by instalments, or for any other form of credit, made to finance the sale of goods". Both the Convention and the Regulation have the same wording.

This category is related to the first one. These are contracts, which are concluded in order to finance the payment of the goods which are purchased under one of the contracts included in the first category. Its inclusion responds to two premises. First, these contracts involve the same risks for the consumer's interests as the main contract. Financing contracts may also include clauses detrimental to the consumer. ${ }^{56}$ If the provisions only applied to the instalment sales, the consumer would be half protected.

\footnotetext{
55 The ECJ has issued two decisions interpreting this category. In Bertrand, it is sustained that a contract of sale on instalment credit terms is an autonomous notion: it is a transaction in which the price is discharged by way of several payments or which is linked to a financing contract. However, in Mietz (C-99/96, Mietz v. Internship Yachting Sneek, [1999] ECR I-2299), it is stated that transactions where the price is paid in instalments but where the property is not transferred until the whole sum is paid are not to be included in this category but in Par. 3. Since in these contracts the supplier has not conceded a credit to the consumer, the objective of a special protection is lost.

56 In fact, since the EU is aware of those abuses some Directives have been issued to protect the consumer: Council Directive 87/102/EEC of 22 December 1986 for the approximation of the laws, regulations and administrative provisions of the Member States concerning consumer credits, [1987] OJ 12 February 1987, L 42/48. This Directive
} 
The second reason to include these contracts refers to the beneficial effects of adjudicating jurisdiction to the same courts over contracts which are closely related. If they were to be judged by different courts it can be the case that contradictory answers might be found. It would threaten legal certainty. ${ }^{57}$ Any contract concluded on-line which is specially aimed to finance the purchase of a good would benefit from special protection. It is irrelevant whether the financer is the seller himself or a third person.

\subsubsection{Contracts which Must Fulfil Further Conditions to Benefit from the Special Protection}

This category has the widest scope. The special protection is justified not in the subject matter of the contract but in the circumstances surrounding the contract. Art. 13(3) of the Brussels Convention includes "any other contract for the supply of goods or a contract for the supply of services" as far as two further conditions are met:

"(a) in the State of the consumer's domicile the conclusion of the contract was preceded by a specific invitation addressed to him or by advertising; and

(b) the consumer took in that State the steps necessary for the conclusion of the contract".

This category was included in the modification pursuant to the accession of the UK, Ireland and Denmark. Having noticed that Art. 13 could not cover all the consumer contracts where protection was needed; the paragraph was included to cover any other category of contracts. From the wording of the provision, it can be seen that its aim is to expand the special protection to consumers of contracts concluded at a distance. However, the delegations restrict such protection to passive sales - cases where the consumer does not try to reach the business to pursue any of his products but waits until he gets knowledge of those products thanks to an advertising campaign of the business in his home country. The Giuliano-Lagarde Report on the Convention on the Law Applicable to Contractual Obligations ${ }^{58}$ states that when it is the consumer who takes the steps to acquire the product or service, he renounces to any special protection. The conditions of Par 3 ensure that it is a passive consumer who concludes the contract and therefore the application of the special provisions is justified.

Art. 15 of the Brussels Regulation opts for a broadening of the scope of the contracts falling under this category. New paragraph 3 reads: "in all

has been lastly amended by Council and European Parliament Directive 98/7/EC of 16 February 1998, [1998] OJ 1 April 1998, L 101/17.

57 E. Zabalo Escudero: “Aspectos juridicos ..." p. 120.

58 [1980] OJ 31 November 1980, C 282/1. The Schlosser Report refers such questions to the explanation of Art. 5(2) of the Rome Convention in the Giuliano-Lagarde Report insofar both provisions have a similar content. 
other cases, the contract has been concluded with a person who pursues commercial or professional activities in the State of the consumer's domicile or, by any means, directs such activities to that State or to several States including that State, and the contract falls within the scope of such activities". The new wording of the category implies that the number of consumers, that may rely on the special protection of Section 4, will increase. It brings legal certainty to direct electronic commerce to the extent there is no need to qualify contracts whose subject matter is a nontangible good as "contracts for the supply of goods or contracts for the supply of services". ${ }^{59}$ New Art. 15 applies "in all other cases" regardless of the characterization of the contract.

Taken into account the characterization of on-line consumer contracts as contracts concluded at a distance, under the rules of the Brussels Convention, most of them will qualify for special protection because they fulfil the conditions of Art. 13(3). The application of these conditions to the Internet environment is subject to legal problems, which are studied, in the following pages. However, the residual character of this category has to be stressed. Once a contract meets the requirements under number 1 or 2 , it deserves special protection. Such contracts do not need to meet the conditions stated in number 3 .

The rest of the Chapter will focus on the question of whether online consumer contracts qualify for special protection. I will first explain the conditions these contracts must fulfil under the Brussels Convention and how they apply to the business-to-consumer sector of electronic commerce; later, I will examine the conditions in new Art. 15(3). According to the Schlosser Report, the aim of these conditions is to ensure that "there is a sufficiently strong connection" with the special jurisdiction. Some authors ${ }^{60}$ have criticized the fact that the conditions are required for the third category of contracts and not for the first two categories. While contracts of Par. 1 and 2 receive special protection independently of the active or passive condition of the consumers, contracts of Par. 3 only receive protection when the consumers are passive.

\subsection{Conditions in Art. 13(3) of the Brussels Convention}

a) In the State of the consumer's domicile the conclusion of the contract was preceded by a specific invitation addressed to him or by advertising.

\footnotetext{
59 In this sense, see P. de Miguel Asensio: Derecho privado de Internet, Madrid, Civitas, 2000, p. 408 and ff.

60 L. Carrillo Pozo: "Comentario al Art. 13" ..., p. 269.
} 
Both situations are similar: while advertising is a general invitation to any possible customer (i), a specific invitation - either an offer or a shop invitation - is directed towards a specific individual (ii).

i) Advertising.

There has been some controversy about the legal nature of web sites. The big issue was whether they have to be qualified as "advertising" in the sense of Art. 13(3) or not. The answer to this question has enormous consequences for European business. Internet is of a global nature. Any information, which is made available on Internet, can be accessed from a computer located in any State in the world. In economic terms, this is seen as an advantage since it is in the interest of any business to reach as many customers as possible. Internet has placed SMEs at a similar competitive level as huge companies to the extent that the costs of making business worldwide have been dramatically lowered in some sectors of the economy thanks to the use of web sites. ${ }^{61}$ However, if European courts consider web sites as "advertising", the first condition of Art. 13(3) will be fulfilled as far as access to a web site necessarily precedes the conclusion of a contract. Since web sites can be accessed from any country in Europe, any person domiciled in Europe doing business on Internet should foresee that he could be sued in any Contracting State where a consumer has engaged in a contractual obligation through his web site - that is to say he has concluded a click-wrap agreement. This conclusion harms the interests of European businesses. They have not missed the chance to let the European Institutions know their opinion in some of the frequent workshops, which have been held. ${ }^{62}$ It implies the potential submission of any European on-line business to any court in conventional territory. It has been maintained that the legal costs of that conclusion may bring to an end electronic commerce for small companies and it can dissuade new entrants from doing business on-line.

To avoid this consequence the business sector may argue that web sites are not like advertising and therefore, since the conclusion of the on-line contract is not preceded by advertising, the special provisions of Section 4 are not applicable. On-line consumer contracts should be governed by the general provisions on contracts (Art. 17, 5(1) and 2) instead, or, at least, they should be subject to specific rules of jurisdiction.

To support this argument it is said that Art. 13(3) was thought to be applied to passive sales. In those cases the consumer deserves some protec-

\footnotetext{
61 See "Electronic commerce - An introduction" in http://www.ispo.cec.belecommerce/ answers/introduction.html (Last visit February 2001).

62 Hearing "Electronic Commerce: Jurisdiction and Applicable Law", held in Brussels, on the 8th and 9th November 1999.
} 
tion towards possible abuses of the business such as forum-choice clauses included in the contract. If it is the consumer who looks for the business to purchase one of his products or services, then this is considered an active sale. Since the condition is not met the special provisions are not applied. When a consumer accesses a web site this is an active sale because it is the consumer who looks for the business by accessing the web site where the on-line business has a catalogue of his products or services. Therefore, European businesses would avoid the special provisions on consumer contracts of the Convention.

Before assessing our opinion on this reasoning, some remarks should be made because, even if this reasoning were considered as valid, not every on-line business would avoid the application of Art. 13(3). First, those enterprises which do not limit their activities to Internet but also trade in the real world: once they have advertised their products or services in the press, on the radio or TV in the consumer's residence State, the condition of letter (a) is fulfilled. Whether the contract is concluded on-line or not makes no difference. The Giuliano-Lagarde Report states that those acts reveal the purpose of a retailer to market his products in the country where the consumer resides thus if they conclude a contract both conditions of Art. 13(3) will be met. Second, only interactive web sites are affected by the application of the article. While the placing of these sites in the WWW is enough for the conclusion of contracts, and therefore the appearance of disputes, passive web sites require further steps to be taken, even if it is considered as advertising, The mere placing of passive web sites in the WWW does not imply a danger for on-line businesses to be sued in a distant State. The application of the provision requires the existence of a contractual relationship. As far as they do not enter into negotiations with a consumer, either by e-mail or telephone, disputes cannot arise and the question of the application of Art. 13 does not appear.

Therefore only interactive web sites' owners have a case in here. However, it cannot be held either. Active sales in a conventional world are not the same as active sales in the electronic marketplace. In fact, the second category is more similar to sales which are preceded by advertising than to active sales in a conventional world. Web sites are accessible at any moment, and they are very easy to find by the use of web browsers. Moreover, they do not even require consumers to move from their home if they finally want to purchase the product or service shown at the web site. If these sales made on Internet cannot be considered as passive, they do not fit either the concept of active sales to the extent that the access of the required information is made extremely easy. In fact, it is the form in 
which this information is displayed which leads us to consider web sites as advertising in the sense of the Convention. ${ }^{63}$

Art. 13(3) (a) requires such advertising or commercial communications to reflect that the trader has taken steps to market his goods or services in the country where the consumer resides. According to the GiulianoLagarde Report, "the trader must have done certain acts such as advertising in the press, or on radio or television, or in the cinema or by catalogues aimed specifically at that country". ${ }^{64}$ In my opinion, advertising on a web site is similar to advertising in the press or television, but does the global nature of Internet enable web sites to be specially aimed toward a particular country? By technical means, no. However, some characteristics of a web sites allow us to determine towards which country(ies) it is directed: the language of the site and, specially, the use of disclaimers where the suppliers renounce to do business with consumers domiciled in certain countries. In such a manner the offer is limited to certain countries. These disclaimers must appear on the screen before the consumer concludes the contract. This is the best way for the supplier to prove that his web site was not directed toward certain States. If the country where the consumery access the site is not included in the disclaimer, national courts must interpret that the first condition of Art. 13(3) is met.

ii) Specific invitations.

In principle, electronic mails should be considered "specific invitations" insofar as the invitation is not directed to the general public but to the individuals who own those e-mail addresses. Nonetheless, we should not forget that way of e-mailing that we have called "spam", that may also be considered as advertising. There is no point discussing spam to any extent

63 In France, it has already been sustained that web sites constitute "advertising". See Cour d'appel de Rennes, 1ere Ch. B., Arrêt du 31 mars 2000, Compagnie Financière du Credit Mutuel de Bretagne c. Federation logement consommation et environnement d'Illeet-Vilaine: "Un site internet est susceptible de constituer un support publicitaire: il permet la communication au public de textes et d'images, destinée éventuellement à présenter au public le consultant des marques des services et des marchandises et à inciter à la conclusion de contrats avec les consommateurs potentiels. Le fait que le site ne puisse être consulté qu'après abonnement, et au choix du site par l'usager d'internet, ne change en rien le caractère publicitaire des annonces qui peuvent y être faites. La situation est exactement identique à celle de l'acheteur d'un journal contenant des publicités ..."

64 The Report gives an example: "If a German makes a contract in response to an advertisement published by a French company in a German publication, the contract is covered by the special rule. If, on the other hand, the German replies to an advertisement in American publications, even if they are sold in Germany, the rule does not apply unless the advertisement appeared in special editions of the publication intended for European countries. In the latter case the seller will have made a special advertisement intended for the country of the purchaser". 
since either because they are considered a specific invitation, or because they are considered invitations to the general public, the contract will meet the requirement on letter (a) of Art. 13(3).

b) The consumer took in that State - consumer's domicile - the steps necessary for the conclusion of the contract.

This second condition applies cumulatively. Only if both conditions were present the consumer would be able to rely on the protection afforded by Arts. 14 and 15 of the Brussels Convention. Some comments need to be made about this second requirement.

First of all, in the interpretation of "the steps necessary for the conclusion of the contract": at what moment can it be considered that the consumer has done so? The Schlosser Report refers the question to the Giuliano-Lagarde Report. In the comments to Art. 5(2), first indent which relates to consumer in the same terms as the Brussels Convention - the reporters write "[t]he Group expressly adopted the words the steps necessary on his part in order to avoid the classic problem of determining the place where the contract was concluded. This is a particularly delicate matter in the situations referred to, because it involves international contracts normally concluded by correspondence. ${ }^{65}$ The word steps includes inter alia writing or any action taken in consequence of an offer or advertisement".

What can be considered as "the necessary steps on the consumer's part" in an electronic transaction? The answer to this question will depend on the type of on-line contract. In the case of clickwrap agreements, the consumer takes the necessary steps when he/she introduces the required information and he/she clicks on an "I agree" icon. ${ }^{66}$ When the contracts are concluded by e-mail, either because the web site states so or because the offer or invitation to treat is originally made by e-mail, the consumer takes the necessary steps when he sends a "reply" e-mail to the supplier.

The provision requires the consumer to take those necessary steps to conclude the contract in his state of domicile. How can we determine in on-line transactions in what state the consumer took the necessary steps for the conclusion of the contract?

\footnotetext{
65 This problem is even bigger for contracts concluded on-line.

66 If it is the first purchase that the consumer concludes on that web page, he/she will be required to introduce certain personal data and a credit card number. In that case, fulfilment of that information will constitute part of "the necessary steps on behalf of the consumer". In many web pages, if the consumer has already purchased any good or service from that site, it will be sufficient to click the button to order the product and to enter a code which was provided to the consumer the first time he made a purchase. Visit for example www.amazon.com.
} 
Web sites can be accessed from any computer connected to Internet anywhere in the world. Since the physical location of the computer does not correspond with its virtual location ${ }^{67}$ it can never be conclusively determined where the consumer introduced the required information on the web site.

In case the contract was concluded by e-mail, prima facie, it might seem easier to answer this question according to the following reasoning. If the consumer used his/her own computer: (1) the appropriate software to send e-mails has to be installed in the computer; (2) the consumer needs to contract the access to Internet with a Service Provider which will file the personal data of that user; (3) he will receive an e-mail address which will prove that the e-mail come from a computer which belongs to a particular individual. Hence, it can be stated if the necessary steps to conclude the contract were taken in the domicile of the consumer. ${ }^{68}$ However, how can we determine if the person using the computer was actually the owner of that computer? Moreover, the development of Internet has created two devices, which place obstacles in the way of solving this question even more. First of all, web-based e-mails ${ }^{69}$ allow Internet users to send messages without the need of the appropriate software being installed in their computer. This e-mail works as an interactive web site, which you can access from any computer in the world - let's say from a "cyber café". Second, Service Providers allow you to connect to the Internet not exclusively from one computer but from any computer with an Internet navigator program. ${ }^{70}$ Even in cases where the contract was concluded by e-mail, it is impossible to determine if the necessary steps were taken in the domicile State of the consumer.

Thereby, since this condition is impossible to be proved in on-line consumer contracts, what should we conclude? European businesses will say that the requirement is not met and therefore the special provisions should not apply. Others may consider this condition as not existing for on-line consumer contracts insofar as it is impossible to fulfil. Thus, it suffices that advertising to apply the special provisions preceded the online contract. The solution would require an interpretation from the ECJ,

67 The Internet Protocol Address that a computer receives so that the information it stores can be accessed from any other computer.

68 The consumer can also use authentication procedures. Since those systems work with personal codes, the authority of the message can be easily determined and thereby the domicile of the consumer. However, who can be sure that the person behind the computer was actually the owner of the personal code?

69 See as an example http://www.hotmail.com

70 In order to do so you only have to type in your password and the telephone number, which the Service Provider has attributed. 
which, if it follows the line of the Brussels Regulation, would lead to allowing the application of the special protection to on-line consumer contracts. Such a decision would help in the completion of one of the policies of the European Union: consumer protection. In addition, it would be in accordance with the guidelines provided by the Council and by the OECD, which have already been mentioned. ${ }^{71}$ Fortunately, any misinterpretation is avoided in the new wording of the provision.

\subsection{The Condition of Art. 15(3) in the Brussels Regulation}

Art. 15(3) of the Brussels Regulation has affirmed the will of the European Commission to provide the same protection to Internet consumers as to conventional ones. The provision exclusively requires the contract to have been concluded with a person who pursues commercial or professional activities in the State of the consumer's domicile or, by any means, directs such activities to that State or to several States including that State, and the contract falls within the scope of such activities. The wording of the provision excludes any doubt about the inclusion of on-line consumer contracts in Section 4. The Memorandum for the Commission of the Proposal comes to confirm this interpretation: "The concept of activities pursued in or directed towards a Member State is designed to make clear that point (3) applies where goods or services are marketed via the Internet". ${ }^{72}$ In this

71 In the Council Resolution of the Consumer Dimension of the Information Society, the Council considers as a necessary condition for establishing consumer confidence in electronic commerce the provision of an equivalent level of protection as is available in traditional consumer transactions by the application of existing principles of consumer policy (Recital 6). In particular, the Council invites the Commission to take all possible steps in conformity with Community Law and with the Community's international obligations to ensure that consumers can rely on the relevant rights already provided for by the Brussels and Rome Conventions, inter alia those concerning the applicability of the legislation of the country of residence and concerning easy access to national jurisdiction (Point I (3)).

The Community's international obligations mentioned in the provision relates to the Recommendation of the OECD Council Concerning Guidelines for Consumer Protection in the Context of Electronic Commerce. General principle of that Recommendation is that "Consumers who participate in electronic commerce should be afforded a transparent and effective level of protection for electronic transactions that is equivalent to the level of protection afforded through other forms of commerce" (Principle I). It is also mentioned that "business to consumer cross-border transactions, whether carried out electronically or by more conventional means, are subject to the existing framework of legislation on jurisdiction and applicable law"; and that "in reviewing the rules on conflict of law and jurisdiction, governments should seek to ensure that the framework provides fairness to consumers and business ... and provides the latter with meaningful access to fair and timely dispute resolution and redress without undue cost or burden" (Principle VI. (A)).

72 Page 15. 
sense, the amendment of Art. 15(3) aims to adapt the conditions to benefit from the special protection to electronic commerce, but it does not change the legal regime applicable to consumer contracts.

In Art. 15(3), the difference between advertising and specific invitations has disappeared. It has to be considered that both categories are covered by the broad terms of the provision: "directing his activities by any means". In such a way the question on the interpretation of "advertising" cannot arise anymore. Electronic mails are another form of directing the professional activities of a business to the State of the consumer, similar to web sites, tele-shopping or sales by telephone.

Moreover, the Regulation brings to an end any doubt about "the place where the consumer took the necessary steps" for the inclusion of on-line consumer contracts under the scope of new Arts. 15, 16 and 17. That condition has been deleted. Now Art. 15(3) focuses exclusively on the action taken by the supplier, the Internet service provider. It is enough for an Internet consumer to rely on the Section to prove that the web site was accessible from his state of residence. Only if the business is not directing his commercial activities to the consumer's domicile State, will the condition on Paragraph 3 not be joined, and therefore the consumer will not be able to rely on the special rules of Arts. 16 and 17 .

As has been said, not every on-line business has enough resources to litigate in a distant country. They may want to limit their activities to some States close to their domicile or they may not want to do on-line business at all but only to show a catalogue of their products or services. However, Internet does not give them another option: their web sites can be accessed from any Member State and therefore they risk being sued in any Contracting State if the national judge considers that they were advertising or directing their activities toward the consumer's residence State in the sense of Art. 15(3).

While the Internet industry could not support its position on legal arguments, it remained a question of legal policy whether to change the regime of the Brussels Convention or to maintain the protection of consumers. At last, the Commission took the second option, and the Council agreed with it. A different opinion was supported by the European Parliament.

Although Internet service providers can be affected by this provision and their legal costs can increase, they must be aware that without consumers e-commerce will not flourish. In fact, consumer confidence has been identified as one of the fundamental issues for the development of the business-to-consumer sector of e-commerce. ${ }^{73}$ Moreover, the position

73 See GBDe "Statement on the state of global e-commerce" of 26 September 2000 by Steve Case and Gerald Levin. Available at http://www.gbd.org 
of the consumer in on-line trading is worse than in traditional commerce: for instance, it is a common practice that consumers must pay in advance and they can be victims of misrepresentation of the product or service. Consumer will only trust in e-commerce if they are provided with effective legal redress mechanisms. Notwithstanding judicial proceedings are not always the most efficient mechanism of legal redress for small-amount disputes ${ }^{74}$ the special protective measures must be maintained insofar as the most effective system of providing judicial redress to consumers is by allowing them to sue in the courts of their domicile.

However, this is not the end for electronic commerce. On-line merchants who cannot afford litigation abroad can construe their web sites as passive ones so that the consumer is required to contact the business by traditional means or by e-mail. Since the application of the special protection requires a contract to take place, the consumer may be asked to contact the supplier by telephone, or e-mail, and the latter may decide whether he wants to conclude the contract depending on the consumer's residence State.

In cases where European merchants want to do business on Internet restricting their activities to certain Member States, they may filter the persons with whom they want to deal. The businessman chooses not to contract with particulars which reside in some countries where they cannot afford to litigate. As has been said, and since no efficient technical means have been developed in this respect, ${ }^{75}$ disclaimers placed on the web site must do this filtering where the European business announces that the offer is only valid for some Member States. In those cases it should be understood that the business is not directing his/her activities towards the consumer's residence state. In case on-line businesses do not include those disclaimers, they should be prepared to litigate in any EU country. The burden of proof that the activity was not directed towards that State rests with them.

Service providers found some support to their arguments in the European Parliament whose proposals are analysed in the following chapter. As is explained, they lack legal consistency and they were not taken into account by the Commission or the Council.

\footnotetext{
74 See Chapter V on the role ADRs can play in electronic commerce.

75 That is one of the conclusions that the U.S. District Court for the Eastern District of Pennsylvania reached in the famous ACLU vs. Reno case (June 11, 1996).
} 


\section{The Report of the European Parliament. Alternative Dispute Resolution in EleCtronic COMMERCE}

The European Parliament Report on the Proposal for a Council Regulation on jurisdiction and enforcement of judgements in civil and commercial matters was voted on 21 September $2000 .^{76}$ Most of the adopted amendments concern the regulation of the jurisdiction over Internet consumer disputes. Although the Commission accepted none of them, it is worth analysing these amendments insofar as they postulated alternative solutions to the problem of balancing the interests of professionals and those of the consumers.

First, Amendment 39 provided the inclusion of a new Paragraph in Art. 15 to make even more clear that it only applies to "interactive" web sites.

Second, the role alternative dispute resolution systems - hereafter referred to as ADRs - can play in consumer disputes was assessed. According to Amendment 35, "allowing consumers to sue in the court of their domicile is likely to have a deterrent effect on new entrants to the growing electronic-commerce market". However, it should also be considered that retailers are in a better position to litigate and to insure against the risk of litigation and that the flourishing of electronic commerce depends on the confidence of consumers towards this new kind of commerce. In order to find a balanced solution, the Report proposed the promotion of the use of alternative dispute resolution systems for on-line consumer disputes so that judicial proceedings should only be necessary as a last resort. For that purpose new Arts. $17 \mathrm{~A}$ and $55 \mathrm{~A}$ were proposed.

\subsection{The Expression "directing such activities" and a New Paragraph in Art. 15}

The EP wanted to include, in Art. 15, the following Paragraph to make clear the meaning the expression "directing such activities" has in the context of Internet:

"The expression "directing such activities" shall be taken to mean that the trader must have purposefully directed his activity in a substantial way to that other Member State or to several countries including that Member State. In determining whether a trader has directed his activities in such a way, the courts shall have regard to all the circumstances of the case, including any attempts by the trader to ring-fence his trading operation against transactions with consumers domiciled in particular Member States."

This amendment sought to make clear that mere Internet advertising passive web sites - is not enough to grant jurisdiction to the courts of

76 Document A5-0253/00, drafted by Ms. Diana Wallis. 
the consumer's domicile; and that the fact that an interactive web site is accessible from any country does not mean that the provider is directing his activities to all the Member States. To reach that conclusion all the circumstances of the particular case must be taken into account, and in particular whether the business has tried to ring-fence his trading operation to a particular Member State. This means that if a trader has included disclaimers restricting the Member States towards which his web site is directed, this shall be taken into account to deny the jurisdiction of the courts of those States to the extent that the professional was not directing his activities toward those States.

Such a Paragraph would not have modified in substance the regulation of on-line consumer contracts jurisdiction. Art. 15 in the Commission Proposal could be interpreted in such a manner without the introduction of the proposed paragraph. First, because application of Art. 15(3) requires the conclusion of a contract - it reads "in all other cases, the contract has been concluded ..." - and, by definition, passive web sites do not allow a contract to be concluded on the web site itself, unless further steps are taken on behalf of the consumer - by sending an e-mail or by fax, etc. Consumers cannot claim non-contractual obligations under the special rules of Arts. 15-17. Second, as the Commission explains in the Memorandum on its Modified Proposal that Art. 15 does not apply to passive web sites. ${ }^{77}$ Finally, the interpretation given to Art. 13 of the Brussels Convention - which constitutes a precedence of Art 15 - in the Schlosser Report $^{78}$ also suggests that the advertisement should have been specially directed toward a specific country.

In the last term, the Paragraph could have been included to please the wishes of part of the Internet industry. However the Commission did not accept it to the extent it was not in accordance with the spirit of the provision. It shall be recalled that the definition of the criteria of "directing his activities" is taken from the US case law. It is a notion that is not commonly used in the European judicial systems. Moreover, the criteria of "right-fencing" can turn superfluous if eventual technological developments would allow to restrict the countries where the activities are directed by technical means thus disclaimer might not be needed anymore. ${ }^{79}$

\footnotetext{
77 See comments to the Amendments on Art. 15 in the Amended Proposal for a Council Regulation on jurisdiction, recognition and enforcement of judgements in civil and commercial matters (COM (2000) 689 final, 26 of October 2000). Available at http://www.uaipit.com

78 The Schlosser Report of the Brussels Convention refers the question to the GiulianoLagarde Report of the Rome Convention.

79 See comments on page 6.
} 


\subsubsection{What Role Can ADRs Play in Electronic Commerce? A New Art. $17 \mathrm{~A}$}

The concept of alternative dispute resolution systems covers any kind of extra judicial dispute resolution mechanisms. ${ }^{80}$ There are already a lot of kinds of these systems dealing with consumer disputes in many fields of economy: banking, immovable property, and insurance. ... They might be of a public or private nature and, depending on the binding effects of their decisions and the procedure, they can be basically classified in arbitration, mediation or conciliation. Insofar as they are a manifestation of the power to exercise jurisdiction, regulation of ADRs has remained the competence of the Member States thus very different systems have been developed from one Member State to another. ${ }^{81}$

In 1998, the Commission stated that ADRs constitute one of the alternatives to judicial proceedings to warrant consumers' right of a quick access to court and legal redress. ${ }^{82}$ On the one side, judicial proceedings are expensive, slow, and very formalistic. Consumers usually think that starting a judicial proceeding is not worthwhile, taking into consideration the usually small amount of consumer claims. Many times, the costs of litigation are higher than the amount of money the consumer wants to claim. These characteristics dissuade consumers from going to court to claim their rights. Even more so if they have to litigate in a third state. On the other side, ADRs are cheaper, quick and the procedure is very flexible, the main objective being to reach a friendly settlement by the parties.

The features of the disputes that on-line consumer contracts can raise are similar to those which are submitted to ADRs in the different countries: small amount of money, the consumer is the weak party in the contractual relationship. ... Being so, the use of ADRs can be expanded to the Internet world. ${ }^{83}$ Moreover, the characteristics of e-commerce add a factor

${ }^{80}$ For further information, E. Mendez Pinedo, La protección de consumidores en la Unión Europea, Marcial Pons, Madrid-Barcelona, 1998, pp. 369 and following.

81 See Commission Green Paper on Consumer access to justice and the settlement of consumer disputes in the single market (Doc. COM (1993) 576 final of 16 November 1993).

82 Communication from the Commission on the out-of-court settlement of consumer disputes (Doc. COM (1998) 198 final of 30 March 1998). The antecedents of that Communication are in the Commission "Green Paper on the access of consumers to justice and the settlement of consumer disputes in the single market" COM (1993) 576 final of 16 November 1993) and the Commission "Action plan on consumer access to justice and the settlement of consumer disputes in the internal market" of 14 November 1996 (OJ [1996] 2 December 1996, C 362/275).

${ }^{83}$ For information on the different ADR systems in electronic commerce see V. Tilman, "Arbitrage et nouvelle technologies: alternative cyber dispute resolution", Revue Ubiquité, 1999, $N^{\circ}$ 2, pp. 47-64; and M. Wilikens, A. Vahrenwald, P. Morris, Out of Court Dispute 
that makes the use of ADR in this sector more important than in the rest of the business activities: the increase of cross-border transactions. This implies that more consumer complaints will be filed against professionals that are domiciled abroad. Therefore the reluctance to start proceedings will increase in consumers.

Both the Commission and the Council have adopted legal instruments on this matter. In Recommendation 98/257, ${ }^{84}$ the Commission stated seven principles with which ADRs of an arbitration nature should comply. Those bodies should be considered to offer the same guarantees as judicial courts, and they were included in a list, which is published in DG SANCO's web site ${ }^{85}$ Furthermore, the project of the creation of a European Extra Judicial Network - EEJ Net - linking all accredited ADRs through central clearing houses is been studied. As the Council Resolution on a Community-wide network of national bodies for the extra-judicial settlement of consumer disputes ${ }^{86}$ states, the use of electronic means of communication in such Networks is essential for the transfer of information between ADRs and for the submission of complaints through a web site. ${ }^{87}$ In all these texts enhancement of ADRs in e-commerce is remarked. Moreover, the Community and all the Member States have agreed in such international fora as the OECD, on the need to promote the use of these systems. ${ }^{88}$

This shows that all the EC institutions agree that ADRs constitute the best alternative to protect consumers' interest while not harming the interests of the industry and not hindering the flourishing of electronic commerce. However the way ADR systems should be involved in the resolution of on-line consumer disputes is not clear.

The EP Report proposed the introduction of a new specific rule of jurisdiction for on-line consumer contracts where ADR are mentioned. Art. 17 A authorized service providers to include on their web sites clauses

$\overline{\text { Settlement }}$ systems for e-commerce, available at http://dsa-isis.jrc.it/ADR (last visited, February 2001).

84 Commission Recommendation 98/257 on the principles applicable to the bodies responsible for out-of-court settlement of consumer disputes OJ [1998] 17 April 1998, L 115/31. In order to regulate non-arbitration ADR schemes, the Commission has just adopted a Recommendation of 4 april 2001 on the principles applicable for out-of-court bodies involved in the consensual resolution of consumer disputes [2001] OJ of 19 April, L 109/51.

85 http://europa.eu.int/comm/consumers/policy/developments/acce_just/index_en.html (last visited, February 2001).

86 [2000] OJ of 6 June 2000, C 155/1.

87 In the same sense, Art 17 of Directive 2000/31 on Electronic Commerce obliges Member States to promote the use of electronic means for out-of-court dispute settlement systems.

88 Principle VI B of the OECD Recommendation. 
referring any dispute to an extra judicial dispute resolution system - EDRs. These systems should have been accredited under a scheme approved by the Commission and the agreement must fulfil certain conditions. In cases where service providers have included those clauses and the conditions of Art. $17 \mathrm{~A}$ are satisfied, the agreement prevails over the rules on jurisdiction of Arts. 16 and 17. The conditions are the following:

a) the consumer must be informed:

- of his right under EC Law to sue and be sued in the courts of the Member State where he is domiciled;

- of the advantages of referring the dispute to an accredited EDR system;

b) the consumer must be provided with a link to the EDR system web site;

c) the consumer must positively acquiesce to the inclusion of the clause;

d) both, the trader and the consumer, agree:

- to be bound by the outcome of the EDR;

- and not to sue in the courts of the consumer's domicile except in order to resolve a point of law or in order to enforce any award or settlement reached under the EDR system.

d) the consumer cannot proceed with the transaction unless he has positively accepted or rejected the clause.

According to Paragraph 3, such clauses shall be presumed to have been individually negotiated for the purpose of Directive 93/13 on Unfair Terms in Consumer Contracts. ${ }^{89}$

Furthermore, new Art. 55 A, introduced by Amendment 41, would have allowed the enforcement of settlements reached under an accredited EDR system in any Member State pursuant to the provisions in Chapter III of the Regulation.

Notwithstanding the important role that ADRs can play in providing effective consumer redress mechanisms; the European Parliament proposal had certain problems preventing its approval. Some of them dissuaded the Commission from including the amendments in its Amended Proposal. First, the Regulation was not the adequate instrument to regulate this issue. Second, even if it could have been admitted, there are certain legal obstacles to be considered: why shouldn't these clauses be subject to Directive 93/13? The fact that a system of accreditation has not yet been developed; the recognition of EDRs decisions is not the same as judicial

89 See infra. 
judgments or a public document, thus the same system should not be applied.

Art. 1(2) of the Regulation excludes arbitration from its scope of application. According to the Court of Justice, such exclusion also covers the agreement to submit a dispute to arbitration. ${ }^{90}$ Being so, in order to determine jurisdiction to verify whether the conditions of Art. 17 A are met, national laws apply. The result can be that while the court of the consumer's domicile has jurisdiction over the dispute, a court in another Member State is deciding on the validity of the agreement of Art. 17 A.

The provision contravenes the position adopted by the European institutions in the field of ADR and access to justice according to which consumers can never be deprived of their right to bring the dispute before a judicial court. That is stated in Commission Recommendation 98/25791 that reflects the case law of the European Court of Human Rights and it is against some Member States' Constitutional law. ${ }^{92}$ This means that consumers cannot be obliged to bring the case before an ADR instead of a judicial court. The second option must always be opened at the time the dispute arises. The legality of Art. $17 \mathrm{~A}$ in accordance with this stated law is doubtful. Furthermore, in certain Member States the inclusion of those clauses in the contract are considered as unfair terms..$^{93}$

In the same sense, it is very arguable that the legality of Par 3 whose objective is to avoid the possibility that the agreement would be considered unfair in accordance to Directive 93/13. Only those terms which have not been individually negotiated can be declared unfair, ${ }^{94}$ thus the agreements on Art. 17 A could never be declared unfair. This would have constituted an important and very arguable decrease in the level of consumer protection as far as the supplier actually drafts these agreements and they can hide important abuses to the detriment of consumers' interests. Even if an agreement complies with the four conditions, those abuses can arise, thus the submission of agreements of Art. 17 A to the Unfair Terms rules is needed.

\footnotetext{
90 Case 190/89, Marc Rich vs. Società Italiana Impianti, [1991] ECR I-3855.

91 V. Principle of liberty: "The decision taken by the body may not result in the consumer being deprived of the protection afforded by the mandatory provisions of the law of the State in whose territory the body is established. In the case of cross-border disputes, the decision taken by the body may not result in the consumer being deprived of the protection afforded by the mandatory provisions applying under the law of the Member State in which he is normally resident in the instances provided for under Article 5 of the Rome Convention of 19 June 1980 on the law applicable to contractual obligations"

92 See Amended Commission Proposal, p. 5.

93 That is the case of the "clause compromisoire" in the French legislation.

94 Art. 3(1) of Directive 93/13.
} 
There is, however, the possibility that control of the agreements can be done by the accredited ADR themselves. However, the systems of accreditation and those requirements have not yet been elaborated by the institutions. In this sense the Commission has included in the Amended Proposal a new Recital 14 A. It refers to the need to review in the near future the possible use of forum-choice clauses in consumer contracts and the need for accelerating the work in process concerning alternative dispute resolution systems.

Proposal of Art. 17 A would be incomplete if it would not be accompanied by new Art. 55 A. ADR decisions in cross-border disputes would lack effectiveness without a simplified system of recognition and enforcement. At this moment, there is not such a system, thus in those cases in which one of the parties does not comply with the settlement, the other party must start a judicial proceeding. The EP Report tries to provide an early solution by applying the same system of recognition and enforcement that the Regulation provides for public and authentic documents. ${ }^{95}$ The idea should be welcome, but it requires to be reconsidered. First, ADRs vary from state to state; many of them are of a private nature. The guarantees of a fair trial and the respect for the rule of law that a private ADR can give are not the same as public authorities provide. ${ }^{96}$ The system should exclusively apply to ADRs of a public nature. Second, even if the

\footnotetext{
95 Article 54 (New Art. 57): 1. A document which has been formally drawn up or registered as an authentic instrument and is enforceable in one Member State shall, in another Member State, be declared enforceable there, on application made in accordance with the procedures provided for in Articles 38, et seq. The court with which an appeal is lodged under Article 43 or Article 44 shall refuse or revoke a declaration of enforceability only if enforcement of the instrument is manifestly contrary to public policy in the Member State addressed.

2. Arrangements relating to maintenance obligations concluded with administrative authorities or authenticated by them shall also be regarded as authentic instruments within the meaning of paragraph 1 .

3. The instrument produced must satisfy the conditions necessary to establish its authenticity in the Member State of origin.

4. Section 3 of Chapter III shall apply as appropriate. The competent authority of a Member State where an authentic instrument was drawn up or registered shall issue, at the request of any interested party, a certificate using the standard form in Annex VI to this Regulation.

Article 55 (new Art. 58): A settlement which has been approved by a court in the course of proceedings and is enforceable in the Member State in which it was concluded shall be enforceable in the State addressed under the same conditions as authentic instruments. The court or competent authority of a Member State where a court settlement was approved shall issue, at the request of any interested party, a certificate using the standard form in Annex $\mathrm{V}$ to this Regulation.

96 Amended Commission Proposal, p. 6.
} 
Commission would have accepted these cases, Art. 1 of the Regulation should have been modified insofar as recognition of arbitrary awards are excluded, and many of the ADR decisions may be of that nature.

One of the purposes of the EEJ-Net is to create a system enabling the Central Information Houses to enforce in its territory the settlements, which have been adopted by ADRs located in other Member States.

Due to these legal problems, the amendments of the Parliament were all rejected and the initial text of the Commission Proposal was finally adopted in the Council.

\section{FinAl REMARKS}

Once Regulation 44/2001 has been adopted, the actual regime of consumer contracts in Arts. 13-15 of the Brussels Convention is deemed to disappear in less than a year. However, it is sustained that new Arts. 15 to 17 will not incorporate significant changes to the existing legal treatment of on-line consumer contracts. None the less, it serves to clarify that consumer's benefit from the same level of protection whether they conclude the contract by traditional means or by electronic means.

For that reason the Brussels Regulation is to be welcomed. It provides an efficient protection to consumer interests. Although it impairs the interests of small companies doing business using interactive web sites, it is a cost they must assume if they want to expand their scope of trading activities. That cost is necessary because if consumers do not feel protected, they will not trust in electronic commerce. In cross-border transactions the best way to provide that confidence is ensuring that individual consumers can always claim at home.

However, ADRs constitute a good alternative to judicial proceedings. If a consumer finds the same level of guarantees in an ADR as in a judicial court and the procedure and cost of the trial is relaxed, he will trust in electronic commerce. On the other hand, professionals prefer to go to an ADR rather than to the courts of the consumers' domicile. Therefore, consumers' and professionals' associations and public authorities must work on the development of efficient out-of-court dispute settlement systems. If these systems are efficient there is no need to include provisions such as Art. 17 A to oblige consumers to go to ADR before going to court. Consumers will go on their own initiative. Moreover, if they are forced to submit the dispute to an ADR they might lose some confidence in them. Therefore, regulation of ADRs must be independent from that of the jurisdiction of judicial courts. 
Being so, judicial proceedings will be the last resort. This means that application of Art. 15 of the Regulation can be minimised. However, the disposition is based on this scheme of consumer protection. It is fundamental to enhance consumers' confidence in electronic commerce and it is the provision that forces professionals to work on the creation of effective ADR systems so that they can avoid its application in on-line consumer contracts.

\section{ACKNOWLEDGEMENTS}

The author would like to thank the persons who helped, one way or another, in the writing of this article: Lucia Marín, Lydia Esteve, Raul Lafuente, Pedro Ferrer and Manuel Morán from the University of Alicante; Dani, Maria, Naira and Jorge; Caroline Wood; Manuel Desantes and Jose Luis Iglesias. 